\title{
Conversion of organic compounds into biogas on a full scale brewery WWTP using IC reactor
}

\author{
Katarzyna Umiejewska ${ }^{1, *}$ \\ ${ }^{1}$ Warsaw University of Technology, Faculty of Building Services, Hydro and Environmental \\ Engineering, ul. Nowowiejska 20, 00-653 Warsaw, Poland
}

\begin{abstract}
Wastewater from breweries usually contains high levels of organic components, which are generally easily biodegradable. Ideally, the mainstream method of brewery wastewater treatment is based on biological transformation, which have been reported to be effective in efficiently reducing COD concentration. Anaerobic digestion technology plays an important role in the treatment of high strength wastewater [1]. The benefit of the process is biogas production and recovering the energy. The main goal of the paper is to present the results of a full-scale research performed in a brewery WWTP in 2016. Wastewater from brewery containing COD, a priority pollutant of organic components, is treated in IC reactor. The biogas produced during the anaerobic digestion is transformed into heat. Total COD and soluble COD were measured 5 days a week in wastewater before and after anaerobic reactor. In raw wastewater, average total COD was $5226 \mathrm{mg} / \mathrm{L}$ with the percentage share of soluble COD $89.4 \%$. As a result of anaerobic treatment $83,7 \%$ reduction of total COD and $92.9 \%$ reduction of soluble COD were obtained. The average daily biogas production was $4089 \mathrm{~m}^{3} / \mathrm{d}$.
\end{abstract}

\section{Introduction}

The amount of water needed to brew beer is several times the volume actually brewed. Large volumes of water are being used by the industry to produce beer for two distinct purposes: as the main ingredient of the beer itself and as part of the brewing process for steam raising, cooling, and washing of floors, packaging, cleaning of the brew house during and after the end of each batch operation [2]. The beer brewing process generates large amounts of wastewater. Brewery wastewater typically has a high chemical oxygen demand (COD) from all the organic components (sugars, soluble starch, ethanol, volatile fatty acids, etc.) $[4,5]$. Janhom et al. [3] have reported that the majority of organic compounds are in dissolved form. Wastewater usually has temperatures ranging from $25^{\circ} \mathrm{C}$ to $38^{\circ} \mathrm{C}$, but occasionally reaching much higher temperatures. The $\mathrm{pH}$ levels can range from 2 to 12 and are influenced by the amount and type of chemicals used in cleaning and sanitizing $[4,5]$. The brewery wastewater is characterized by large variations in the parameters and require some degree of

\footnotetext{
* Corresponding author: katarzyna.umiejewska@pw.edu.pl
} 
pretreatment. If the brewery wastewater is discharged into the waterway, primary and secondary treatment is required. However, if the brewery is permitted to discharge into a municipal sewer, pretreatment may be required to meet municipal bylaws or to lessen the load on the municipal treatment plant [5]. Due to the organic compounds and high temperature, anaerobic purification is justified. Anaerobic treatment of brewery wastewater allows for removal of about $90 \%$ of the BOD. Furthermore, anaerobic treatment generates biogas - a renewable energy. In this paper, the results of an application of a full scale IC reactor in Poland will be presented, with particular attention drawn to the conversion of organic compounds into biogas.

\section{Materials and methods}

The research was conducted at the brewing pretreatment plant in 2016. WWTP was designed for a flow of $5500 \mathrm{~m}^{3} / \mathrm{d}$ and COD of $4000 \mathrm{mg} / \mathrm{L}$.

The first part of the treatment system is the screen. Next, sewage flows into equalisation tank. Biological treatment takes place in the IC reactor of $24 \mathrm{~m}$ height and a capacity of $1192 \mathrm{~m}^{3}$. The temperature of the wastewater in the reactor should be $35^{\circ} \mathrm{C}$.

The maximum OLR assumed for this project is $18.5 \mathrm{~kg} \mathrm{COD} / \mathrm{m}^{3} \cdot \mathrm{d}$. Biogas formed in the fermentation process is cleaned.

Treated wastewater is discharged into the sewer. TCOD value at the effluent should be lower than $1400 \mathrm{mg} / \mathrm{L}$.

Samples of influent and effluent from the reactor were taken 5 days a week. The scope of the research included the measurement of the following parameters:

TCOD - Hach cuvette test LCI 400, LCK514, LCK 914,

SCOD - centrifuge of the sample (3500 rpm, $t=10 \mathrm{~min})$, Hach cuvette test LCI 400, LCK514, LCK 914,

TSS - PN-EN 872:2007

The $\mathrm{pH}$ was measured on-line. The daily volume of biogas was measured and calculated to the volume of the biogas produced from influent $\mathrm{COD}\left(\mathrm{V}_{\mathrm{COD}}\right.$ in $)$ and removed COD ( $\left.\mathrm{V}_{\text {CODrem }}\right)$. Moreover, ORL and HRT were calculated. Influents into IC reactor were characterized by pollution indicators presented in the Table 1.

Table 1. Characteristic of influents into IC reactor.

\begin{tabular}{|c|c|c|c|c|c|c|c|c|}
\hline Parameter & $\mathbf{p H}$ & $\begin{array}{c}\text { Flow } \\
\mathbf{\mathbf { 3 } ^ { \mathbf { 3 } } / \mathbf { d }}\end{array}$ & $\begin{array}{c}\text { TCOD, } \\
\mathbf{m g} / \mathbf{L}\end{array}$ & $\begin{array}{c}\text { SCOD, } \\
\mathbf{m g} / \mathbf{L}\end{array}$ & $\begin{array}{c}\text { SCOD/TCOD, } \\
\mathbf{\%}\end{array}$ & $\begin{array}{c}\text { TSS, } \\
\mathbf{m g} / \mathbf{L}\end{array}$ & $\begin{array}{c}\text { VSS, } \\
\mathbf{m g} / \mathbf{L}\end{array}$ & $\begin{array}{c}\text { VSS/TSS, } \\
\mathbf{\%}\end{array}$ \\
\hline Average & 9.03 & 2345 & 5717 & 5226 & 89.4 & 763 & 546 & 72.3 \\
\hline Minimum & 5.35 & 47 & 443 & 368 & 64.5 & 74 & 64 & 51.6 \\
\hline Maximum & 12.48 & 3339 & 9350 & 8305 & 100 & 2550 & 1425 & 93.8 \\
\hline
\end{tabular}

In an IC reactor, organic compounds are converted into biogas. Soluble organic substances with a low molecular weight such as sugar, alcohol and fatty acids are readily biodegradable. The data collected in Table 2 demonstrates the characteristics of effluents from IC reactor.

Table 2. Characteristic of effluents from IC reactor.

\begin{tabular}{|c|c|c|c|c|c|c|c|}
\hline Parameter & $\mathbf{p H}$ & $\begin{array}{c}\text { TCOD, } \\
\mathbf{m g} / \mathbf{L}\end{array}$ & $\begin{array}{c}\text { SCOD, } \\
\mathbf{m g} / \mathbf{L}\end{array}$ & $\begin{array}{c}\text { SCOD/TCOD, } \\
\mathbf{\%}\end{array}$ & $\begin{array}{c}\text { TSS, } \\
\mathbf{m g} / \mathbf{L}\end{array}$ & $\begin{array}{c}\text { VSS, } \\
\mathbf{m g} / \mathbf{L}\end{array}$ & $\begin{array}{c}\text { VSS/TSS, } \\
\mathbf{\%}\end{array}$ \\
\hline Average & 6.78 & 945 & 377 & 41.7 & 578 & 482 & 83.6 \\
\hline Minimum & 6.31 & 220 & 172 & 18.2 & 260 & 190 & 71.2 \\
\hline
\end{tabular}




\begin{tabular}{|l|l|l|l|l|l|l|l|}
\hline Maximum & 7.48 & 2392 & 1533 & 78.2 & 1733 & 1350 & 92.8 \\
\hline
\end{tabular}

\section{Results and discussion}

\subsection{COD conversion}

Figure 1 shows the TCOD and SCOD in the wastewater influents into the anaerobic reactor and the percentage share SCOD into the TCOD.

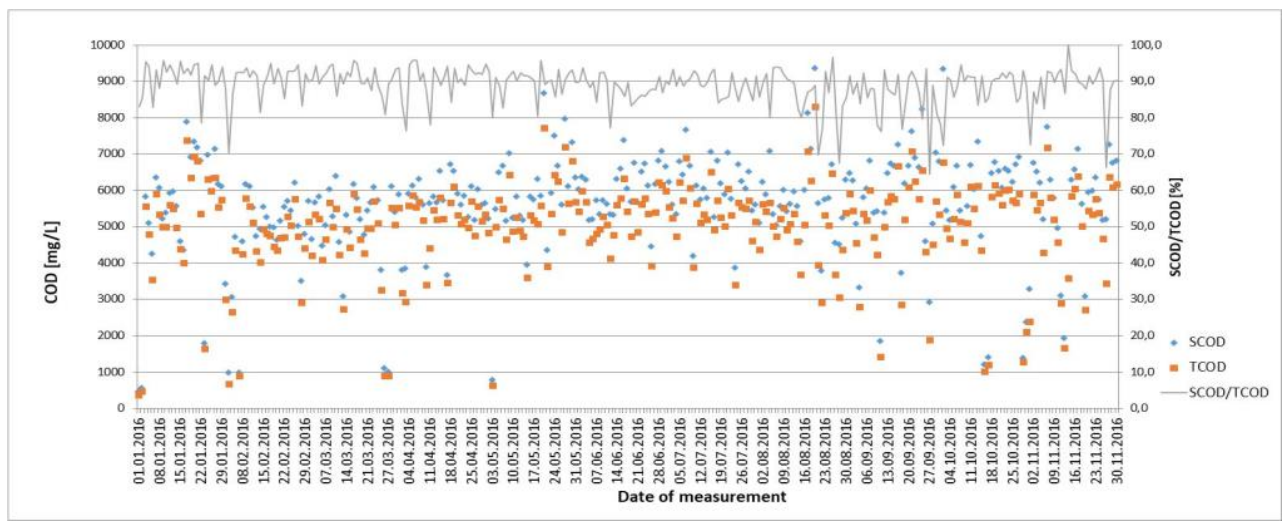

Fig. 1. TCOD and SCOD in raw wastewater.

In 2016, the COD value in raw sewage was measured 282 times (Figure 1). The average annual COD was $5717 \mathrm{mg} / \mathrm{L}$ and amounted to $143 \%$ of the value assumed for the project. Results higher than the COD assumed for the project constituted $83 \%$ of the data. The highest value was recorded on $19^{\text {th }}$ of August and it was $9350 \mathrm{mg} / \mathrm{L}$, and the lowest was $443 \mathrm{mg} / \mathrm{L}$ $\left(\right.$ January $\left.1^{\text {st }}\right) .47 \%$ of results surpassed the average. Over the year, most of the results $(72 \%)$ were in the range of $4500-7000 \mathrm{mg} / \mathrm{L}$. According to the data presented by Oktem [6], the typical COD value in brewery wastewater was in the range of $200-6000 \mathrm{mg} / \mathrm{L}$, but actual values exceeded this range. The value of soluble COD (SCOD) is of particular importance in the decomposition of organic substances in anaerobic reactors with a short HRT. The average annual SCOD was $5226 \mathrm{mg} / \mathrm{L}$. The highest value was recorded on $19^{\text {th }}$ of August $8305 \mathrm{mg} / \mathrm{L}$, the lowest was $368 \mathrm{mg} / \mathrm{L}$ ( $1^{\text {st }}$ of January). SCOD higher than the average constituted $49 \%$ of results. Over the year, most results $(80.0 \%)$ were listed between $4000-6500 \mathrm{mg} / \mathrm{L}$. The soluble fraction constituted $89.4 \%$ of total organic compounds. The highest percentage share was $100 \%$ - on the November $13^{\text {th }}$, and the lowest $(64.5 \%)$ on September $27^{\text {th }}$. Most results were between $90-95 \%$ and $85-90 \%$, respectively $47.3 \%$ and $32.9 \%$. In 2016, 225 results were analysed. The average annual TCOD in sewage effluents from the IC reactor was $945 \mathrm{mg} / \mathrm{L}$. The highest result $-2392 \mathrm{mg} / \mathrm{L}-$ was recorded on $13^{\text {th }}$ of October. That day, a low COD reduction (67\%) was observed. The lowest COD was measured on January $3^{\text {rd }}(220 \mathrm{mg} / \mathrm{L})$. A high reduction of these parameters $(82 \%)$ was achieved then. 93\% of COD value after anaerobic treatment met the requirements of the regulation concerning the industrial wastewater discharge into the sewage system $1400 \mathrm{mg} / \mathrm{L}$. Treated sewage was dominated by values in the range of 500-1000 mg/L, which accounted for $60.0 \%$ of the results. The average annual SCOD value was $377 \mathrm{mg} / \mathrm{L}$. The highest result $-1533 \mathrm{mg} / \mathrm{L}$ - was recorded on $13^{\text {th }}$ of October, when the lowest SCOD reduction $(75 \%)$ occurred. The lowest value was observed on January $3^{\text {rd }}(172 \mathrm{mg} / \mathrm{L})$. In 
January, an increase SCOD values was noticed, with only 2 results below the average. The values from the scope of $250-500 \mathrm{mg} / \mathrm{L}$ were dominant, which accounted for $82.7 \%$ of all results.

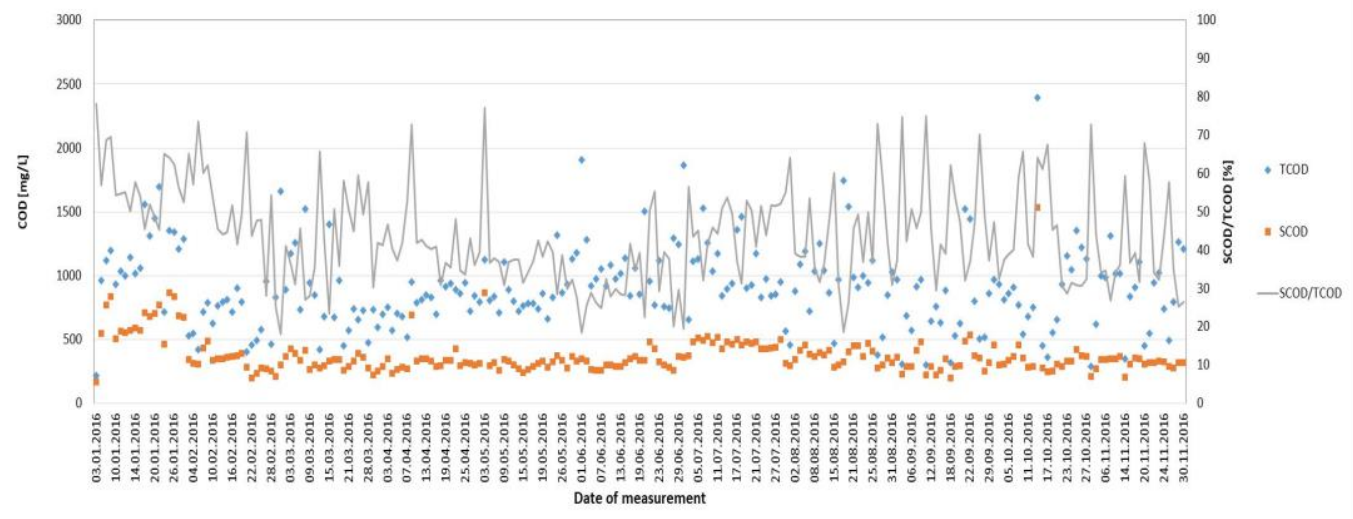

Fig. 2. TCOD and SCOD in wastewater effluent from IC reactor.

The average annual percentage share of SCOD in the TCOD amounted to $41.7 \%$. It was significantly lower than in raw sewage, which accounted to $89.4 \%$. This confirms the effective operation of the IC reactor, which removed organic pollutants in a dissolved form. The highest share was recorded on January $3^{\text {rd }}-78.2 \%$. It should be noted that the lowest share in the effluent from the IC reactor (18.2\%) occurred on March $1^{\text {st }}$, when the SCOD/TCOD in raw sewage was $90 \%$. Most results were in the ranges of 30-40\% and $40-50 \%$, which represented $30.7 \%$ and $26.2 \%$ respectively.

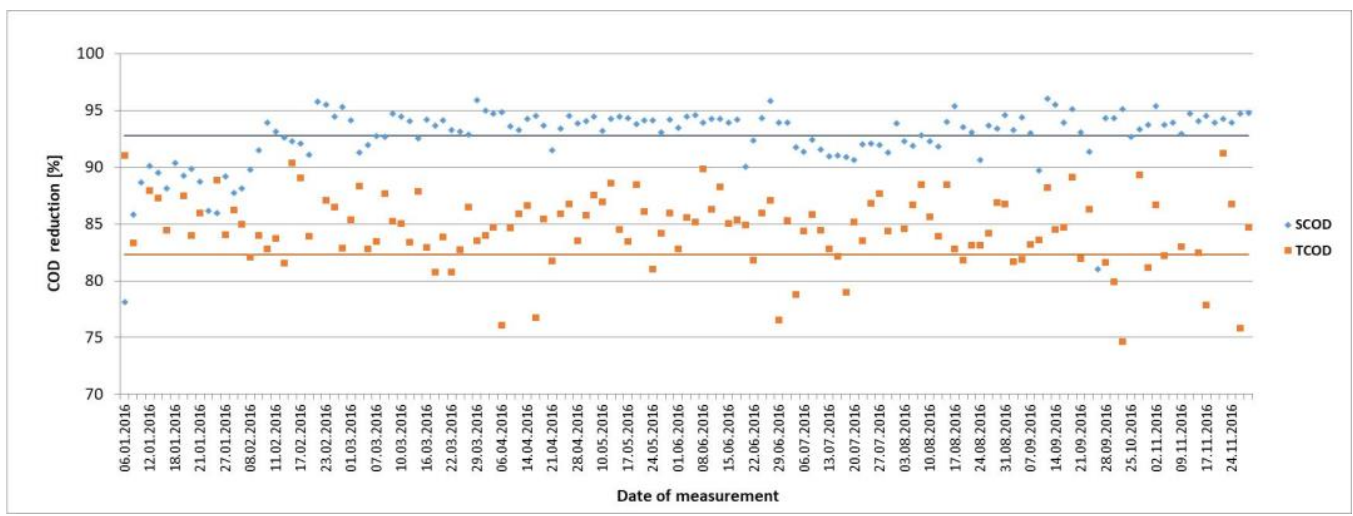

Fig. 3. TCOD and SCOD removal efficiency.

The average annual TCOD reduction was $83.7 \%$. This result is representative of anaerobic digestion process in the IC reactor reported in the literature (over $80 \%$ ). The minimum reduction occurred on $31^{\text {st }}$ January (45.3\%). At that time, the COD value in raw sewage was very low $-966 \mathrm{mg} / \mathrm{L}$. For one of the highest COD values in raw wastewater $(8108 \mathrm{mg} / \mathrm{L})$, the reduction was $78.5 \%$. The maximum removal efficiency $(91.8 \%)$ took place on $7^{\text {th }}$ of April, when the COD value in raw sewage was $6300 \mathrm{mg} / \mathrm{L}$. The most frequent 
interval was $80-90 \%$, which concerned $76.7 \%$ of all the results. The reduction of COD lower than $70 \%$ was achieved only 6 times and the reduction higher than $90 \%$ was recorded 15 times.

The average decrease of SCOD was $92.9 \%$. The minimum percentage reduction happened on $13^{\text {th }}$ October $(74.9 \%)$. The maximum reduction $(96.1 \%)$ was recorded on $13^{\text {th }}$ September. The dominant results were in the range $90-95 \%$, which accounted for $76.8 \%$ of all the data. $11.9 \%$ of the results were recorded in the range of $95-100 \%$. A greater reduction of the SCOD fraction was observed than in the case of the reduction of the total COD value.

\subsection{Biogas production}

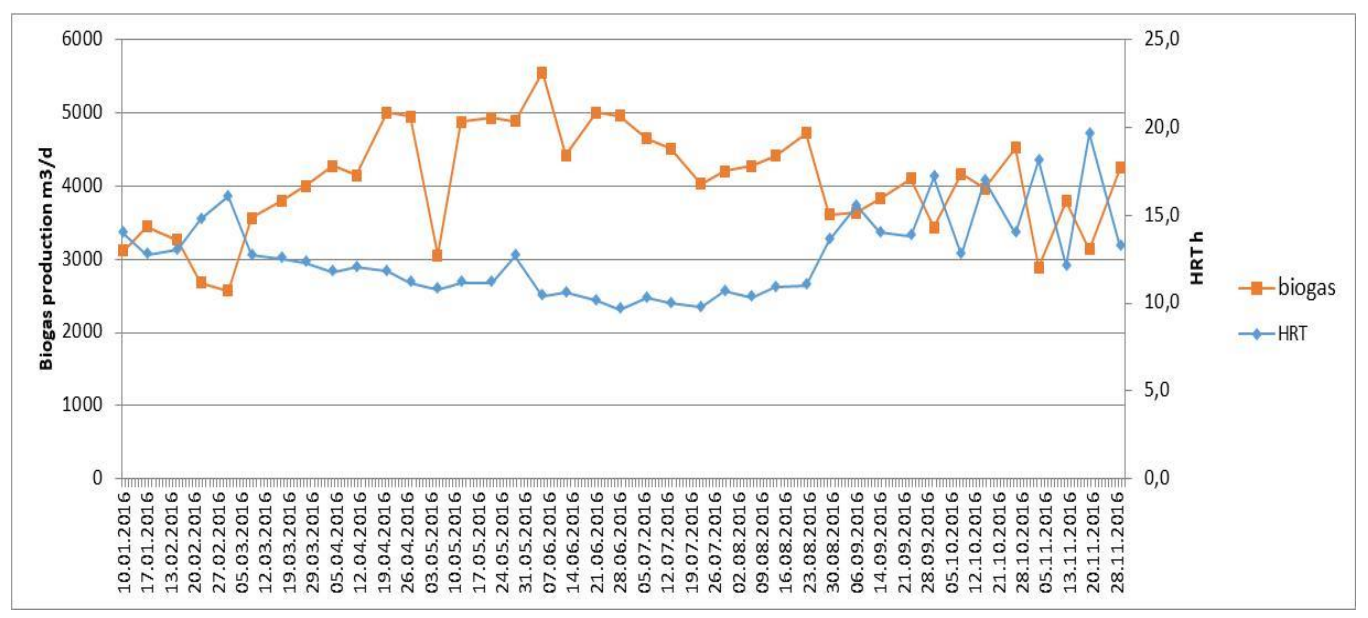

Fig. 4. Biogas production vs HRT.

The average annual biogas production was $4089 \mathrm{~m}^{3} / \mathrm{d}$. The highest result fell on $20^{\text {th }}$ April $\left(6653 \mathrm{~m}^{3} / \mathrm{d}\right)$, the lowest $-128 \mathrm{~m}^{3} / \mathrm{d}$ on $3^{\text {rd }}$ May. In summer months, due to higher loads of organic pollutants (higher production), there were fewer low results compared to the rest of the year. The most frequent range was $4000-5000 \mathrm{~m}^{3} / \mathrm{d}$ (30.7\% of records), $26.8 \%$ of data was in the range $5000-6000 \mathrm{~m}^{3} / \mathrm{d}$. In order to facilitate the interpretation of the obtained data, figure 4 presents the average weekly biogas production in comparison with the actual HRT. In the literature, the HRT for an IC reactor accounts to 4-12h. The actual HRT was $11.9 \mathrm{~h}$. The highest result was noted on $17^{\text {th }}$ October and amounted to $53.8 \mathrm{~h}$, the lowest $8.6 \mathrm{~h}$ was recorded on $21^{\text {st }}$ July. One of the factors influencing the production of biogas is HRT. In theory, shortening the HRT should make the biogas production lower. The highest average weekly production of $5521 \mathrm{~m}^{3} / \mathrm{d}$ was recorded at HRT $=10.4 \mathrm{~h}$. The data in Figure 4 do not support this thesis. However, from September to December 2016, increases HRT caused increases in biogas production.

The average annual OLR was $13.2 \mathrm{~kg} \mathrm{COD} / \mathrm{m}^{3} \cdot \mathrm{d}$. All OLR values were lower than the maximum value characterizing the functioning of IC reactors $-40 \mathrm{~kg} \mathrm{COD} / \mathrm{m}^{3} \cdot \mathrm{d}$. The highest OLR occurred on July $15^{\text {th }}$ and amounted to $20.6 \mathrm{~kg} \mathrm{COD} / \mathrm{m}^{3} \cdot \mathrm{d}$, the lowest OLR $3.0 \mathrm{~kg} \mathrm{COD} / \mathrm{m}^{3} \cdot \mathrm{d}$ was recorded on October $9^{\text {th }}$. It should be noted that only 8 results exceeded the value assumed for the project $18.5 \mathrm{~kg} \mathrm{COD} / \mathrm{m}^{3} \cdot \mathrm{d}$. No significant correlation between biogas production and OLR was observed. 


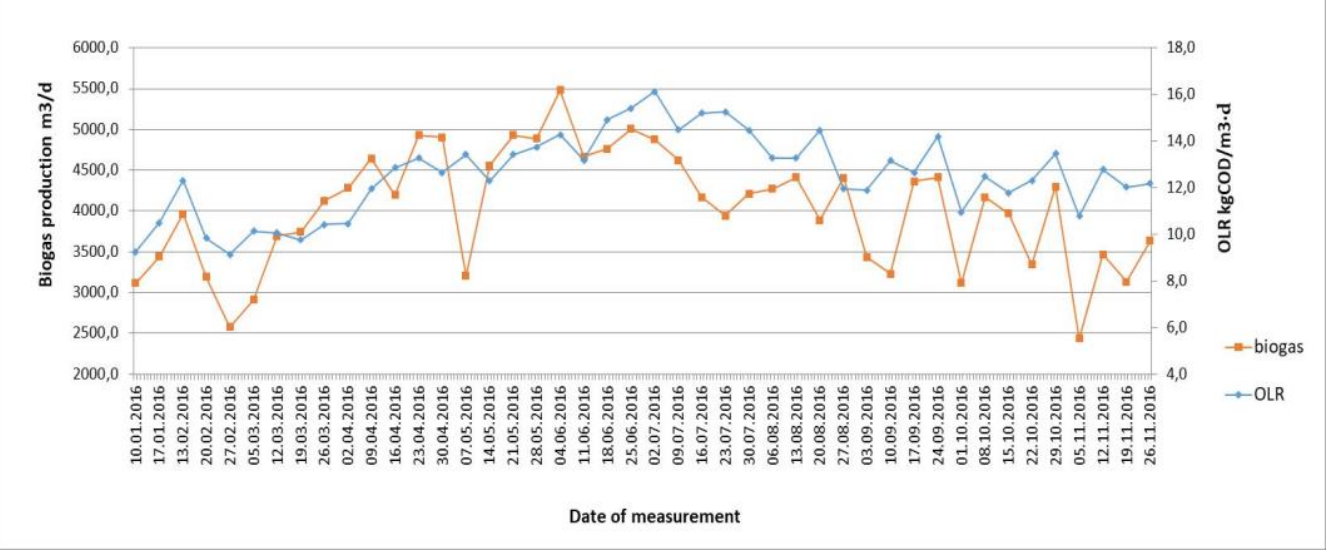

Fig. 5. Biogas production vs OLR.

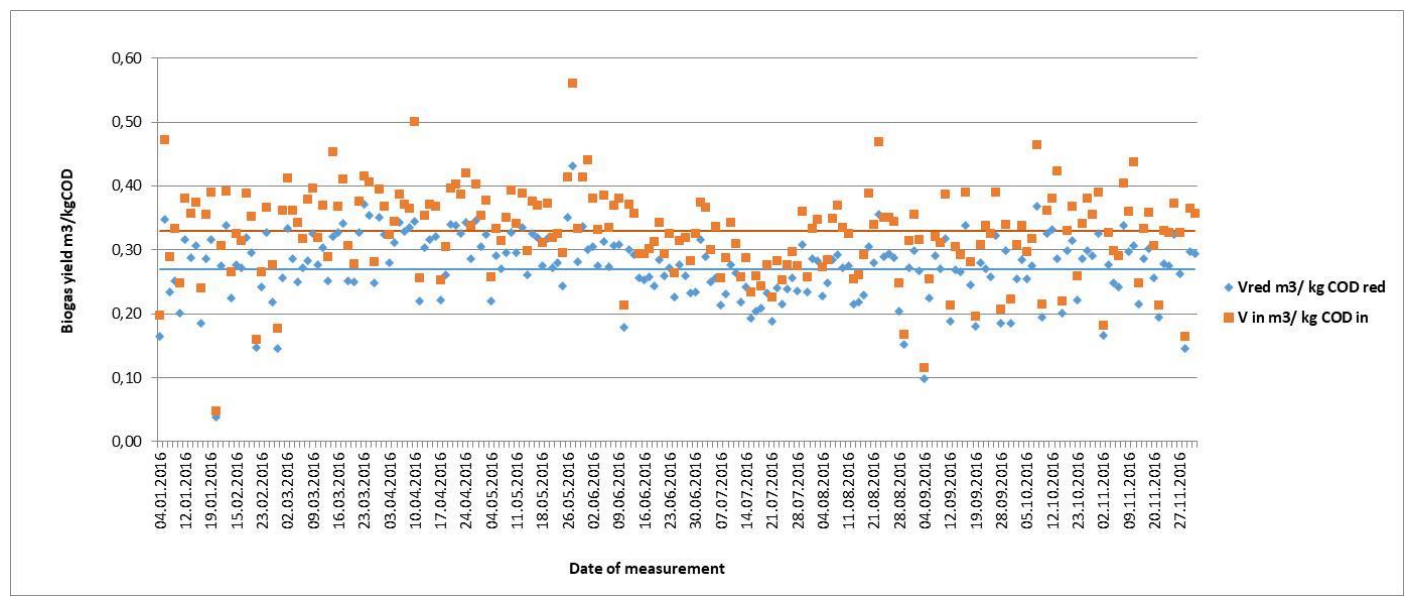

Fig. 6. Biogas yield.

The biogas yield was $0.29 \mathrm{~m}^{3} / \mathrm{kg} \mathrm{COD}$ in. The highest value of $0.99 \mathrm{~m}^{3} / \mathrm{kg} \mathrm{COD}_{\text {in }}$ was recorded on $15^{\text {th }}$ October, while the minimum value on $20^{\text {th }}$ January $0.04 \mathrm{~m}^{3} / \mathrm{kg} \mathrm{COD}$ in.

The dominant range $0.2-0.3 \mathrm{~m}^{3} / \mathrm{kg} \mathrm{COD}_{\text {in }}$ contained $52.6 \%$ of records. The second largest range was $0.3-0.4 \mathrm{~m}^{3} / \mathrm{kg} \mathrm{COD}$ in $(34.2 \%$ of the results).

Typically anaerobic treatment of brewery wastewater generates about $0.4-0.5 \mathrm{~m}^{3}$ of biogas per $\mathrm{kg}$ of COD removed.

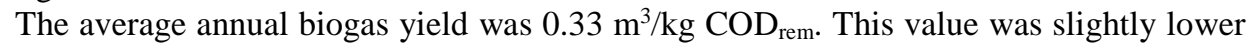
than the theoretical. Chen et al. [1] suggest that the AnMBR can achieve a COD removal higher than $98 \%$ while treating brewery wastewater, with a biogas yield level at $0.53 \pm 0.015 \mathrm{~m}^{3} / \mathrm{kg}$ COD. The highest result was noted on $25^{\text {th }}$ September $-1.25 \mathrm{~m}^{3} / \mathrm{kg}$ $\mathrm{COD}_{\text {rem }}$, while the minimum result of $0.05 \mathrm{~m}^{3} / \mathrm{kg} \mathrm{COD}$ rem was recorded on $20^{\text {th }}$ January.

The dominant records were in the range of $0.3-0.4 \mathrm{~m}^{3} / \mathrm{kg} \mathrm{COD}$ rem, the share of which was $58.2 \%$. The second most numerous range was $0.2-0.3 \mathrm{~m}^{3} / \mathrm{kg} \mathrm{COD}$ rem $(26.4 \%$ of records). On the other hand, the share of a range typical for brewing sewage $0.4-0.5 \mathrm{~m}^{3} / \mathrm{kg} \mathrm{COD}$ rem, was $8.2 \%$. 


\section{Conclusion}

The conducted research confirmed the high efficiency of anaerobic processes for the treatment of brewing wastewater. The high content of dissolved organic compounds (89.4\%) predestines this effluent for treatment in anaerobic reactors with a short retention time. The actual average HRT of $12.9 \mathrm{~h}$ is close to the maximum time given in the literature. Biogas production is influenced by: the content of easily decomposable organic compounds in wastewater, process temperature, HRT, OLR. No correlation between biogas production and HRT or OLR was confirmed during the study. Unit biogas production was $0.29 \mathrm{~m}^{3} / \mathrm{kg} \mathrm{COD}_{\text {in }}$ and $0.33 \mathrm{~m}^{3} / \mathrm{kg} \mathrm{COD}$ rem. The biogas produced in the digestion process is conversed into heat.

\section{References}

1. H. Chen, S. Chang, Q. Guo, Y. Hong, P. Wu, Biochem. Eng. J. 105, part B, 321-331 (2016)

2. A. M. Enitan, J. S. Kumari, F. M. Swalaha, F. Bux, World Acad. Sci. Eng. Technol. 9, 1073-1076 (2015)

3. T. Janhom, S. Wattanachira, P. Pavasant, J. Environ. Manage. 90, 2, 1184-90 (2009)

4. T. Goldammer, The Brewers' Handbook (2 ${ }^{\text {nd }}$ edition Apex Publishers, Clifton, 2008)

5. G. S. Simate, J. Cluett, S. E. Iyuke, E. T. Musapatika, S. Ndlovu, L. F. Walubita, A. E. Alvarez, Desalination 273, 235-247 (2011)

6. Y. Oktem, N. Tufecki, JSIR 65, 248-251 (2006) 